\title{
EXPERT E-PRESCRIPTION APPLICATION (EEPA) USING FORWARD CHAINING METHOD
}

\author{
Nova Eka Diana, Dwi Agung Saputra \\ Universitas Yarsi \\ Jl. Let. Jend Suprapto Cempaka Putih, Jakarta Pusat 10510 \\ Telp: (021) 4206675, Fax: (021) 4243171 \\ E-mail: dwiagungsaputra791@gmail.com
}

\begin{abstract}
Medical errors in reading doctor's handwritten prescription are common in hospitals. These problems may harm the patient's conditionif the pharmacist misreads a recipe given by the doctor. Therefore, Electronic prescribing (e-prescription) system is urgently needed to overcome faults in recipe prescription process. Pharmacist or medical staff can easily read a handwritten recipe by using an eprescription application. Here, we develop Expert E-Prescription Application (EEPA) utilized with recipe recommendation feature based on the disease symptoms. In this application, there are three types of user with the different access rights for each of them; doctor, pharmacist, and receptionist. EEPA facilitate the receptionist in registering, filling, and updating patient data. Doctor can generate a recommended recipe by typing the symptoms and also view the history of patient medical records. Pharmacist can also check patient's prescription and give a medicine based on patient id number. Test result of this application which justified by the expert (doctor) give the accuracy of $91,67 \%$.
\end{abstract}

\section{Abstrak}

Seiring dengan kesulitan yang dialami oleh beberapa tenaga medis dalam membaca resep obat dari dokter, diperlukan sebuah resep elektronik (e-prescription) dalam pemberian obat kepada pasien. Hal ini untuk mengurangi terjadinya kesalahan dalam pemberian obat terhadap pasien. Resep elektronik (e-prescription) bertujuan untuk memudahkan proses pembacaan resep yang ditulis oleh dokter sertamampu merekomendasikan resep obat secara otomatis. Keberadaan resep elektronik (eprescription) dapat membantu tenaga medis dalam memberikan pelayanan kepada pasien, meliputi proses pendaftaran, pemeriksaan dan pemberian obat di rumah sakit. Pada penelitian ini penulis mencoba membuat aplikasi resep elektronik (e-prescription) dengan menggunakan metode forward chaining. Dalam hal ini gejala digunakan sebagai fakta dan selanjutnyadigunakan untuk menarik kesimpulan mengenai suatu penyakit. Pada aplikasi ini terdapat tiga jenis pengguna dengan hak akses yang berbeda, yaitu dokter, apoteker dan resepsionis. Dokter dapat melakukan hasil pemeriksaan dan melihat histori pasien pada tabel data pasien. Apoteker dapat melakukan tebus obat berdasarkan hasil pemeriksaan dokter. Resepsionis mampu melakukan pengisian tambah dan ubah data pasien. Hasil uji coba aplikasi terhadap pakar (dokter) menunjukan akurasi 91,67\%.

Kata kunci: sistem pakar, resep elektronik (e-prescription), forward chaining

\section{PENDAHULUAN}

Resep elektronik adalah generasi elektronik dari peresepan melalui proses penambahan data secara otomatis menggunakan perangkat lunak dan jaringan transmisi yang menghubungkan resep dengan apotek. Resep elektronik diharapkan dapat mengganti resep manual, resep yang dicetak komputer dan computer faxed prescription. Untuk menjamin kerahasiaan informasi pasien, resep elektronik dikirimkan melalui jaringan yang aman dan tertutup yang hanya ditujukan untuk kepentingan peresepan (Kusumarini, Dwiprahasto \& Wardani, 2011). Selain itu, penerapan resep elektronik juga dapat digunakan untuk mengurangi terjadinya kesalahan penanganan medis akibat kesalahan pembacaan resep dokter. Penggunaan Computerized Provider Order Entry (CPOE) pada rumah sakit di Amerika Serikat dalam melakukan peresepan obat mampu mengurangi tingkat kesalahan sebesar 48\% di tahun 2008 (Radley et al, 2013).

Pada dasarnya sistem resep elektronik sangat berfungsi sebagai sistem pencatatan, pengolahan, serta pelaporan data pasien dan obat yang diintegrasikan dengan suatu modul perangkat lunak resep elektronik. Sistem ini biasa disebut dengan istilah Electronic Medical Record (EMR). (Soegijoko, 2010) menyebutkan bahwa salah satu manfaat dari resep elektronik adalah untuk mempermudah proses administrasi dan histori penggunaan obat oleh pasien. (Mudzak- 
kir, 2012) juga menyebutkan bahwa sistem resep elektronik adalah pemanfaatan sistem elektronik untuk menfasilitasi dan meningkatkan komunikasi urutan resep atau obat, membantu pilihan, administrasi dan penyediaan sebuah obat melalui pengetahuan dan mendukung keputusan serta penyediaan jejak audit yang kuat untuk seluruh obat-obatan yang digunakan. Pengertian ini menegaskan bahwa peresepan elektronik tidak hanya tentang bagaimana berkomunikasi, tetapi juga mencakup pasokan dan administrasi serta fungsi lainnya seperti audit.

Aplikasi resep elektronik yang dibangun akan lebih mempermudah tugas dokter jika dilengkapi dengan fitur rekomendasi obat sesuai dengan gejala penyakit pasien. Untuk menyediakan fitur ini, aplikasi harus mengadopsi pengetahuan yang dimiliki oleh dokter mengenai peresepan obat dan mengimplementasikannya sebagai aturanaturan untuk memberikan rekomendasi obat. Selanjutnya, rekomendasi resep obat yang diberikan oleh aplikasi harus dijustifikasi tingkat keakurasiannya dengan meminta pendapat dari pakar (dokter). Telah banyak penelitian yang memanfaatkan teknik-teknik ilmu komputer untuk membangun sistem pakar (expert system) maupun sistem penunjang keputusan (decision support system) di berbagai bidang ilmu pengetahuan, baik bidang kesehatan maupun bidang ilmu lainnya. Salah satunya adalah penelitian yang dilakukan oleh (Sasmito, Surarso, dan Sugiharo, 2011) mengenai pembangunan sistem pakar menggunakan teknik forward chaining dan rule based reasoning untuk melakukan diagnosis penyakit pest pada tanaman cabe dan bawang merah. (Ershad, Tajalizadeh, dan Jafari, 2013) juga menggunakan pendekatan pohon keputusan (decision tree) berbasis aturan (rule based reasoning) untuk membangun sistem pakar dalam penentuan pengampu mata kuliah berdasarkan pengalaman dan kualifikasi dari setiap dosen. Dalam penelitian ini, pengetahuan pakar disusun dalam bentuk pohon keputusan untuk menghasilkan aturan-aturan pengambilan keputusan dan selanjutnya dikombinasikan dengan majority voting algorithm untuk menentukan calon dosen terbaik sebagai pengampu mata kuliah. Berdasarkan permasalahan dan teknik komputer tersebut, maka dapat dibangun sebuah resep elektronik ( $e$ prescription) yang membantu tenaga medis dalam memberikan pelayanan kepada pasien dari mulai datang ke rumah sakit, mendaftar, diperiksa dokter dan dalam pemberian obat di rumah sakit supaya tidak terjadi kesalahan oleh pihak tenaga medis dan pasien rumah sakit. Selain itu, aplikasi juga perlu dilengkapi dengan fitur rekomendasi obat berdasarkan penyakit, jenis penyakit, jenis obat, umur dan dosis/aturan obat. Penelitian ini bertujuan untuk membangun sebuah sistem pakar resep elektronik (e-pres- cription) yang dapat memberikan kemudahan kepada para tenaga medis di rumah sakit dalam memberikan pelayanan kepada pasien sehingga tidak lagi terjadi kesalahan yang tidak diinginkan. Sistem mampu memberikan rekomendasi resep secara otomatis berdasarkan nama penyakit, jenis penyakit dan umur pasien. Jumlah penyakit yang dapat diimplementasikan adalah 6 penyakit.

\section{METODOLOGI}

Sistem pakar (Expert System) adalah sistem yang berusaha mengadopsi pengetahuan manusia ke komputer, sehingga komputer dapat menyelesaikan masalah yang seperti biasa dilakukan oleh para ahli. Sistem pakar yang baik dirancang agar dapat menyelesaikan suatu permasalahan tertentu dengan meniru kerja dari para ahli (Fadhilah, Destiani \& Dhamiri, 2012). Komponen yang membentuk suatu sistem pakar dibagi menjadi empat komponen yaitu sebagai berikut:

A. Basis Pengetahuan (Knowledge Base). Jika proses akuisisi data telah selesai dilakukan, maka data tersebut harus direpresentasikan menjadi basis pengetahuan dan basis aturan yang selanjutnya dikumpulkan, dikodekan dan digambarkan dalam bentuk rancangan lain menjadi bentuk yang sistematis.

B. Basis Data (database). Himpunan kelompok data (arsip) yang saling berhubungan yang diorganisasi sedemikian rupa agar kelak dapat dimanfaatkan kembali dengan cepat dan mudah.

C. Mesin Inferensi (Inferensi Engineer). Bagian dari sistem pakar yang melakukan penalaran atau pelacakan dengan menggunakan isi daftar aturan berdasarkan urutan dan pola tertentu. Selama proses konsultasi mekanisme inferensi menguji aturan satu demi satu sampai kondisi aturan itu benar. Ada dua teknik utama dalam mekanisme inferensi, yaitu: forward chaining dan backward chaining. Forward chaining dimulai dengan mengumpulkan informasi yang tersedia dan selanjutnya membuat konklusi baru. Sebaliknya, backward chaining dimulai dengan memberikan ekspektasi/ hipotesis yang diinginkan, dan selanjutnya mencari bukti atau kontradiksi dari hipotesis tersebut (Honggowibowo, 2009).

D. Antar Muka Pemakai (User Interface). Antar muka memberikan fasilitas komunikasi antara pemakai dan sistem, memberikan berbagai keterangan yang bertujuan untuk membantu mengarahkan alur penelusuran masalah sampai ditemukan solusi dan memberikan tuntunan penggunaan sistem secara menyeluruh langkah demi langkah sehingga pemakai mengerti apa yang harus dilakukan terhadap sistem. 
Dalam pengembangan sistem pakar, digunakan pendekatan konvensional dengan metode Expert System Development Life Cycle (ESDLC). Tahap-tahap yang harus dilakukan pada metode ESDLC dapat dilihat pada Gambar 1.

\subsection{Metode Forward Chaining}

Metode forward chaining adalah metode dimana penelusuran di mulai dari mengambil fakta-fakta terlebih dahulu baru kemudian digunakan untuk menarik simpulan. Dalam hal ini gejala digunakan sebagai fakta, setelah semua data gejala terpenuhi dapat digunakan untuk menarik simpulan mengenai suatu penyakit seperti dijelaskan pada Gambar 2. Adapun basis pengetahuan yang digunakan adalah penalaran berbasis aturan (Rule-Based Reasoning) sebagaimana dinyatakan sebagai berikut:

\section{JIKA < kondisi $>$ MAKA <daftar aksi>}

Kondisi disini adalah sekumpulan ekspresi yang merupakan gabungan dari beberapa nilai atribut dan operasi koneksi logika. Misalkan:

JIKA suhu tubuh $>37$ dan muka 'pucat' MAKA pasien terkena flu.

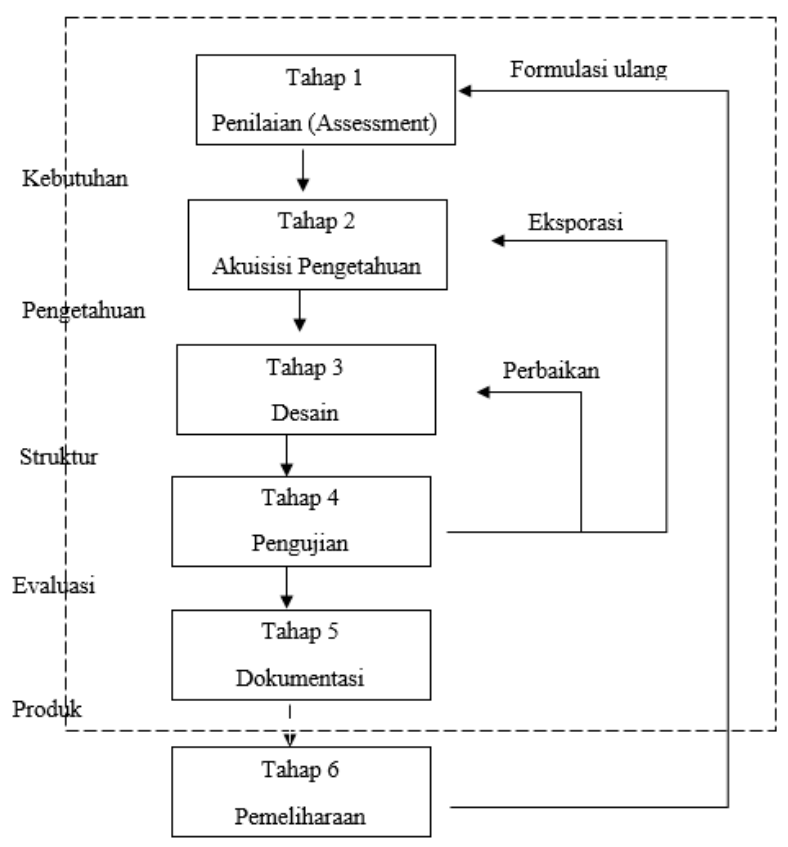

Gambar 1.Tahap Pengembangan Sistem Pakar (Fadhilah, Destian \& Dhamiri, 2012)

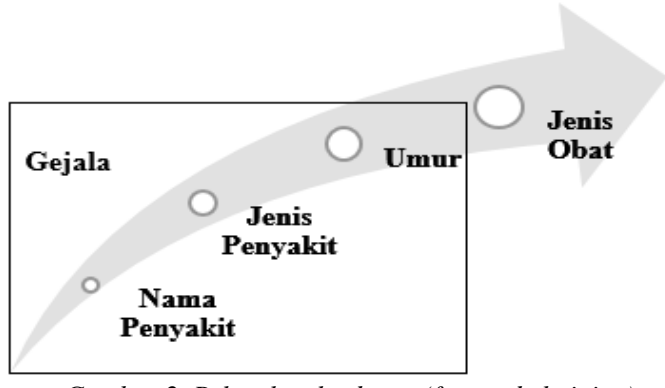

Gambar 2. Pelacakan ke depan (forward chaining)
Pada tahap awal, penulis membuat pohon pengetahuan yang dimulai dari jenis penyakit. Selanjutnya, penyakit ini dibagi-bagi kembali berdasarkan gejala yang muncul dan usia pasien. Akhirnya, pohon pengetahuan akan selesai dengan menghasilkan daun yang merupakan resep obat sesuai dengan jenis penyakit dan usia pasien. Gambar 3 adalah salah satu contoh pohon pengetahuan yang dibangun sebagai basis dalam membangun sistem pakar resep elektronik ini.

Berdasarkan pohon pengetahuan yang sudah dibangun, penulis membuat aturan menggunakan metode forward chaining sebagaimana ditunjukan pada Tabel 1. Selain berdasarkan gejala penyakit dan usia pasien, penulis juga mempertimbangkan jumlah stok obat yang tersedia dalam menentukan jenis obat yang diberikan. Seperti terlihat pada Gambar 3, penyakit batuk dengan tipe ekspektoran (berdahak) bisa diobati dengan beberapa jenis obat, Gliseril Gualikolat, Bromheksin, atau OBH. Pada penelitian ini, obat yang pertama kali diberikan adalah sesuai dengan kemunculan obat seperti tertulis pada sumber yang diperoleh untuk membuat pohon pengetahuan.

Selanjutnya, jika stok obat yang pertama tidak ada, maka pasien akan diberikan obat lainnya sesuai urutan kemunculannya pada pohon pengetahuan. Misalkan penyakit Batuk dan berdahak (ekspektoran), maka terdapat tiga jenis obat yang dapat diberikan. Pasien, akan diberikan Gliseril Gualikolat terlebih dahulu secara otomatis. Obat pertama ini akan digunakan apabila stoknya masih tersedia, tetapi jika sudah habis jumlah stoknya, maka Bromheksin akan digunakan. Kemudian apabila Bromheksin tidak tersedia lagi stoknya maka OBH akan digunakan sebagai pilihan obat untuk ditampilkan pada resep. Proses ini akan berlaku untuk semua jenis penyakit yang diimplementasikan dalam sistem yang dibangun.

Tabel 1. Basis Pengetahuan

\begin{tabular}{l}
\hline \multicolumn{1}{c}{ Aturan } \\
\hline JIKA Batuk DAN Ekspektoran DAN Umur 19 - \\
50 tahun Maka Resep: Gliseril gualikolat 1-2 \\
Tablet (100 - 200 mg) diminum setiap 6 jam \\
atau 8 jam sekali. \\
JIKA Batuk DAN Ekspektoran DAN Umur 6-- \\
12 tahun Maka Resep: Gliseril gualikolat 1/2 \\
tablet (50 - 100mg) diminum setiap 8 jam \\
JIKA Flu DAN Antihistamin DAN Umur $19-$ \\
50 tahun Maka Resep: CTM 1 tablet (2mg) \\
diminum setiap 6 - 8 jam. \\
JIKA Flu DAN Antihistamin DAN Umur 5-12 \\
tahun Maka Resep: CTM 1/2 tablet (1mg) \\
diminum setiap 6 - 8 jam. \\
JIKA Demam DAN Demam DAN Umur 19 - \\
50 tahun Maka Resep: Paracetamol 1 tablet \\
(500mg), diminum 3 - 4 x sehari, (setiap 4 -6 \\
\hline
\end{tabular}


jam).

JIKA Demam DAN Demam DAN Umur 5 - 12 tahun Maka Resep: Paracetamol 1/2 - 1 tablet (250 - 500mg), diminum $3-4$ sehari, (setiap 4 -6 jam).

JIKA Nyeri DAN Nyeri DAN Umur 19 - 50 tahun Maka Resep: ibuprofen 1 tablet 200mg 2 $-4 \mathrm{x}$ sehari diminum setelah makan.

JIKA Nyeri DAN Nyeri DAN Umur 5 - 12 tahun Maka Resep: ibuprofen 1 tablet 500mg, diminum 3 - 4 x sehari.

JIKA Kecacingan DAN Kecacingan DAN Umur 19 - 50 tahun Maka Resep: Pirantel pamoat 2 tablet.

JIKA Kecacingan DAN Kecacingan DAN Umur 10 - 15 tahun Maka Resep: Pirantel pamoat 1 tablet.

JIKA Maag DAN Maag DAN Umur 19 - 50 tahun Maka Resep: Antasida 1 - 2 tablet (200mg), 3 - 4 x sehari 1 jam sebelum makan. JIKA Maag DAN Maag DAN Umur 6-12 tahun Maka Resep: Antasida 1/2 - 1 tablet 3-4 $\mathrm{x}$ sehari 1 jam sebelum makan.

\section{HASIL DAN PEMBAHASAN}

Penulis melakukan pengujian untuk mengukur tingkat akurasi dari aplikasi yang sudah dibangun. Pada aplikasi ini, penulis mengimplementasikan aturan untuk 6 buah penyakit yaitu: batuk, flu, demam, nyeri, kecacingan, dan maag. Pengujian dilakukan dengan melakukan 12x percobaan dengan $2 x$ percobaan/penyakit dengan berbagai kondisi kasus penyakit dan umur. Semua kasus percobaan ini dilakukan terhadap aplikasi yang dibangun dan diberikan kepada pakar (dokter umum) untuk diperiksa. Hasil yang dikeluarkan oleh aplikasi selanjutnya dibandingkan dengan hasil pemeriksaan dokter untuk mengukur tingkat akurasi sistem yang dibangun. Tabel 2 menunjukkan hasil pengujian yang sudah dilakukan terhadap sistem. Percobaan 1\&2 adalah untuk penyakit batuk, $3 \& 4$ adalah untuk Flu, dan seterusnya sesuai urutan kemunculan di Tabel 1. Tabel 3 menunjukkan nilai perbandingan antara hasil pemeriksaan dokter dan resep yang dikeluarkan oleh sistem. Nilai dari setiap percobaan adalah SALAH atau BENAR, salah jika tidak sesuai dengan hasil pemeriksaan dokter dan sebaliknya. Berdasarkan Tabel 3, terdapat satu buah kesalahan hasil pemeriksaan pada kasus percobaan nomor 8 , dimana terjadi perbedaan antara resep yang dikeluarkan aplikasi dan hasil pemeriksaan pakar. Hasil pengujian keseluruhan menunjukkan tingkat akurasi sebesar 91,67\% terhadap keahlian pakar (dokter umum).

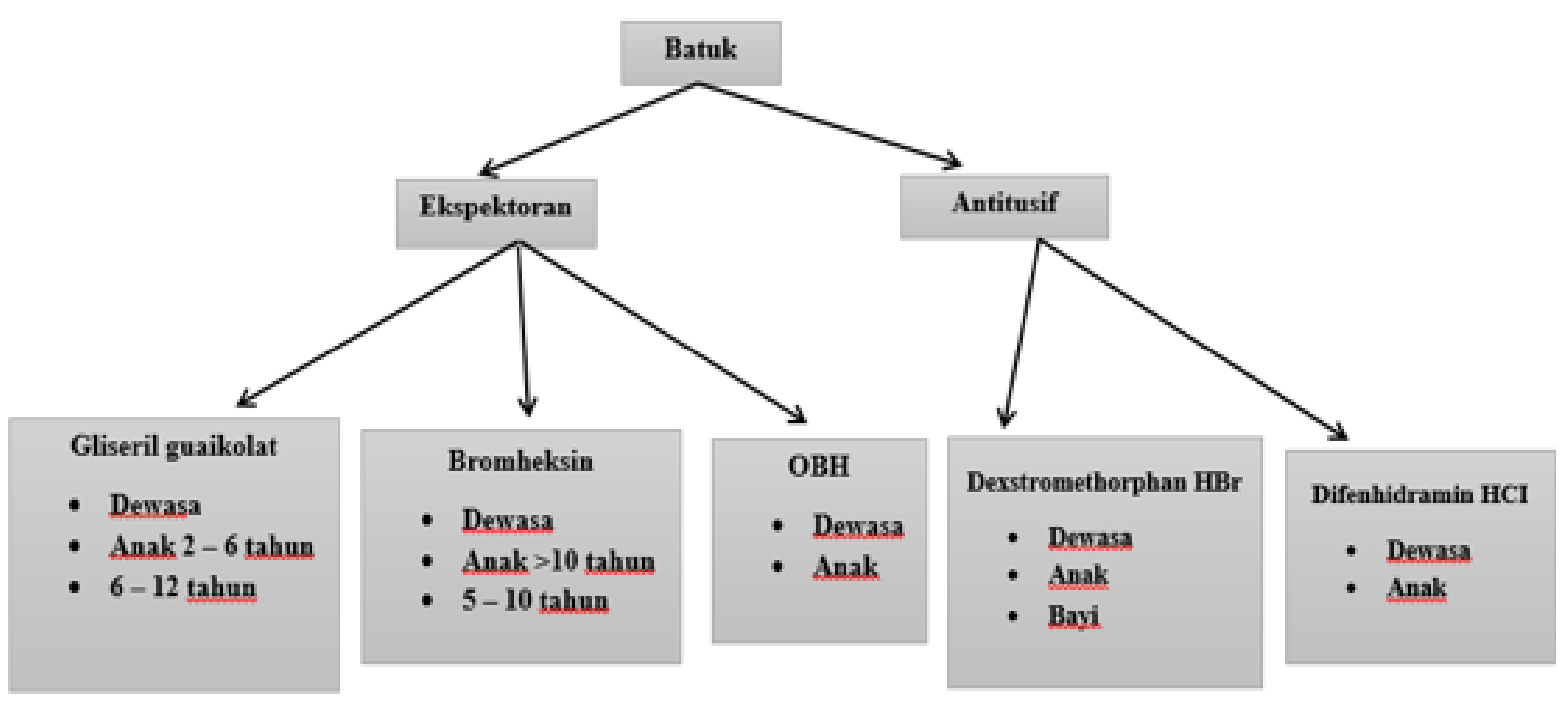

Gambar 3. Pohon pengetahuan penyakit Batuk

Tabel 2. Hasil Pengujian Aplikasi

\begin{tabular}{|c|c|c|c|c|}
\hline $\begin{array}{l}\text { Nama } \\
\text { Penyakit }\end{array}$ & Umur & $\begin{array}{l}\text { Jenis } \\
\text { Penyakit }\end{array}$ & Nama Obat & Resep \\
\hline Batuk & 20 & Ekspektoran & $\begin{array}{l}\text { Gliseril } \\
\text { guaikolat }\end{array}$ & $\begin{array}{l}\text { 1-2 tablet }(100-200 \mathrm{mg}) \text { diminum setiap } 6 \text { jam } \\
\text { atau } 8 \text { jam sekali. }\end{array}$ \\
\hline Batuk & 7 & Ekspektoran & $\begin{array}{l}\text { Gliseril } \\
\text { guaikolat }\end{array}$ & $1 / 2$ tablet $(50 \mathrm{mg}$ ) diminum setiap 8 jam. \\
\hline Flu & 22 & Antihistamin & CTM & 1 tablet $(2 \mathrm{mg}$ ) diminum setiap $6-8$ jam. \\
\hline Flu & 9 & Antihistamin & CTM & $1 / 2$ tablet $(1 \mathrm{mg})$ diminum setiap $6-8$ jam. \\
\hline
\end{tabular}




\begin{tabular}{|c|c|c|c|c|}
\hline Demam & 24 & Demam & Paracetamol & $\begin{array}{l}1 \text { tablet }(500 \mathrm{mg}) \text {, diminum } 3-4 \times \text { sehari, (setiap } 4 \\
-6 \text { jam). }\end{array}$ \\
\hline Demam & 11 & Demam & Paracetamol & $\begin{array}{l}1 / 2-1 \text { tablet }(250-500 \mathrm{mg}), \text { diminum } 3-4 \text { sehari, } \\
\text { (setiap } 4-6 \text { jam). }\end{array}$ \\
\hline Nyeri & 26 & Nyeri & Ibufrofen & $\begin{array}{l}1 \text { tablet 200mg } 2-4 \text { x sehari diminum setelah } \\
\text { makan. }\end{array}$ \\
\hline Nyeri & 8 & Nyeri & Ibuprofen & 1 tablet $500 \mathrm{mg}$, diminum $3-4 \mathrm{x}$ sehari. \\
\hline Kecacingan & 28 & Kecacingan & $\begin{array}{l}\text { Pirantel } \\
\text { pamoat }\end{array}$ & 2 tablet. \\
\hline Kecacingan & 10 & Kecacingan & $\begin{array}{l}\text { Pirantel } \\
\text { pamoat }\end{array}$ & 1 tablet. \\
\hline Maag & 30 & Maag & Antasida & $\begin{array}{l}1-2 \text { tablet }(200 \mathrm{mg}), 3 \times 4 \text { sehari } 1 \text { jam sebelum } \\
\text { makan. }\end{array}$ \\
\hline Maag & 12 & Maag & Antasida & $1 / 2-1$ tablet $3-4 x$ sehari 1 jam sebelum makan. \\
\hline
\end{tabular}

Tabel 3. Hasil Perbandingan Sistem dan Pakar

\begin{tabular}{lc}
\hline Hasil Percobaan & $\begin{array}{c}\text { Hasil Aplikasi Resep } \\
\text { Elektronik dan Hasil } \\
\text { Dokter }\end{array}$ \\
\hline Percobaan Ke 1 & Benar \\
Percobaan Ke 2 & Benar \\
Percobaan Ke 3 & Benar \\
Percobaan Ke 4 & Benar \\
Percobaan Ke 5 & Benar \\
Percobaan Ke 6 & Benar \\
Percobaan Ke 7 & Benar \\
Percobaan Ke 8 & Salah \\
Percobaan Ke 9 & Benar \\
Percobaan Ke 10 & Benar \\
Percobaan Ke 11 & Benar \\
Percobaan Ke 12 & Benar \\
\hline
\end{tabular}

\subsection{Tampilan Aplikasi}

Berikut ini adalah tampilan Aplikasi Resep Elektronik yang telah berhasil diimplementasikan.

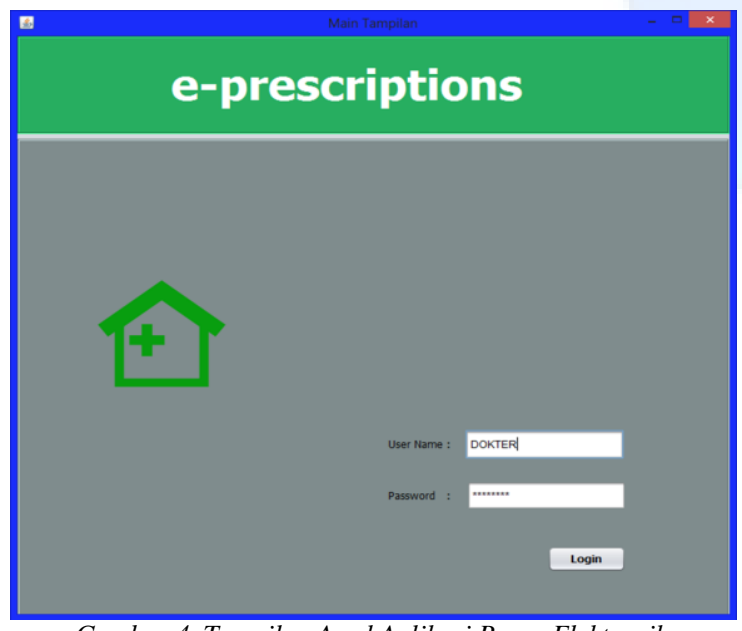

Gambar 4. Tampilan Awal Aplikasi Resep Elektronik

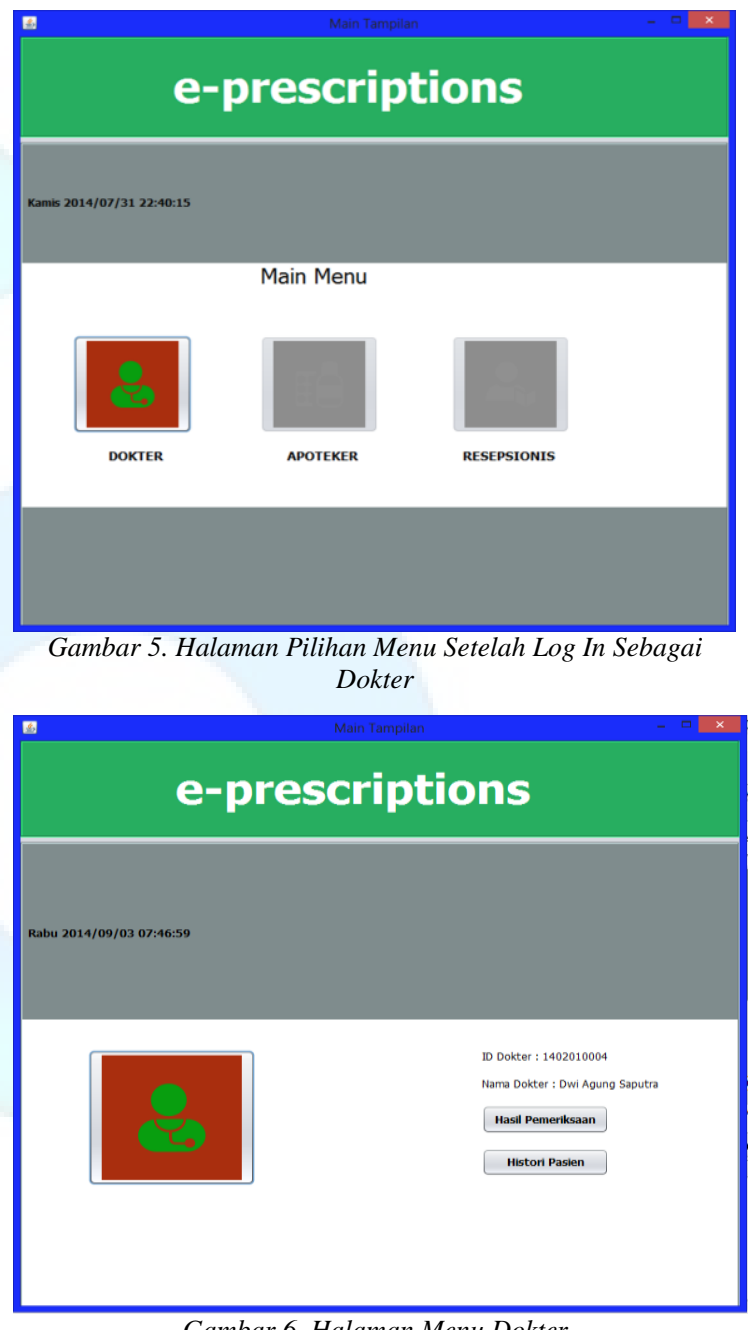

Gambar 6. Halaman Menu Dokter 


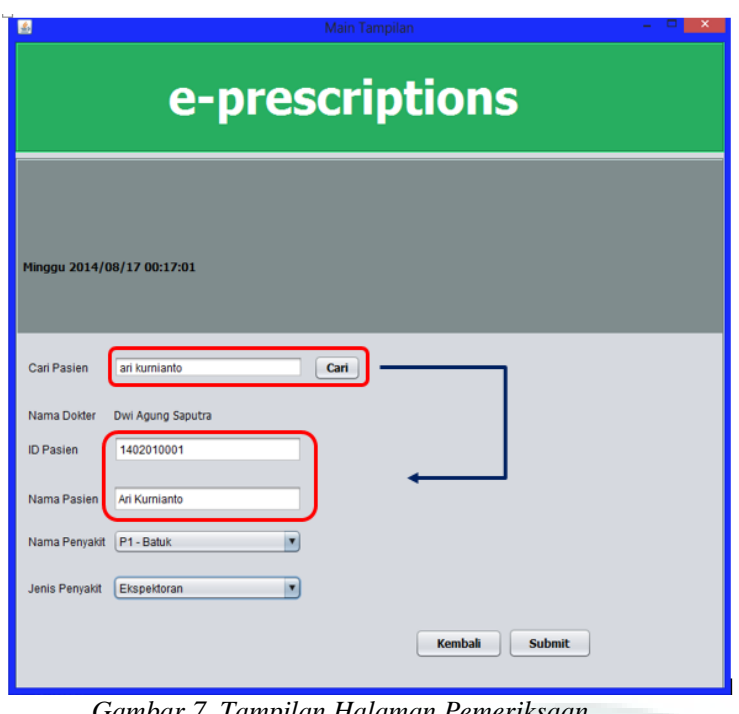

Gambar 7. Tampilan Halaman Pemeriksaan

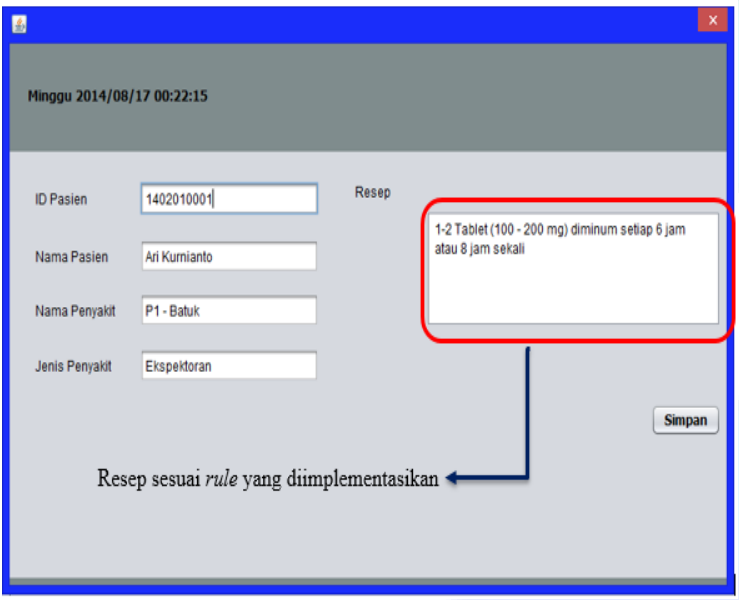

Gambar 8. Tampilan Hasil Pemeriksaan Pasein

\section{SIMPULAN dan SARAN}

Pada penelitian ini telah dibangun sistem pakar resep elektronik bernama Expert E-Prescription Application (EEPA) dengan menggunakan metode forward chaining. Hasil pengujian sistem berdasarkan justifikasi pakar (dokter umum) menunjukkan tingkat akurasi sebesar $91,67 \%$. Sistem yang dibangun dapat dijadikan sebagai landasan untuk mengembangkan sistem pakar resep yang lebih detail dan akurat serta mengadopsi berbagai jenis gejala sebagai penyebab penyakit. Diharapkan aplikasi ini dapat dikembangkan dengan mencantumkan/ menampilkan merek dagang obat dan biaya obat yang harus dibayar, data penyakit dapat ditambahkan untuk waktu yang akan datang, semua rule dapat diperbaiki untuk meningkatkan hasil akurasi pada percobaan aplikasinya, dan fitur untuk penggunanya dapat disesuaikan untuk waktu yang akan datang.

\section{DAFTAR RUJUKAN}

Ershad, S.F., Tajalizadeh, H. dan Jafari, S., 2013, Design and development of an expert system to help head of university departments, International Journal of Science and Modern Engineering (IJISME), issn: 2319-6386, Vol, 1, Issue-2

Fadhilah AN, Destiani D \& Dhamiri DJ, 2012, Perancangan aplikasi sistem pakar penyakit kulit pada anak dengan metode expert system develoment life cycle, Jurnal Algoritma, Sekolah Tinggi Teknologi Garut.

Honggowibowo, AS, 2012, Sistem pakar diagnosa penyakit tanam pada berbasis web dengan forward dan backward chaining, Jurusan Teknik Informatika, Sekolah Tinggi Teknologi Adisutjipto.

Kusumarini, P, Dwiprahasto, I, \& Wardani, PE 2011, Penerimaan dokter dan waktu tunggu pada peresepan elektronik dibandingakan peresepan manual, Jurnal Manajemen Pelayanan Kesehatan, vol. 14, no. 3, pp. 133 $-138$.

Mudzakkir, M, 2012, Sistem resep elektronik (close-loop) berbasis barcode untuk patient safety, Tugas Mata Ajar Sistem Informasi Manajemen, Magister Keperawatan Kekhususan Keperawatan Medikal Bedah, Universitas Indonesia.

Radley, D. C. et al, 2013, Reduction in medication errors in hospitals due to adoption of computerized provider order entry systems, J Am Med Inform Assoc, 00:1-7.

Sasmito, G.W., Surarso, B. dan Sugiharo, A., 2011, Application expert system of forward chaining and the rule based reasoning for simulation diagnose pest and disease red onion and chili plant, Proceedings of the $1^{\text {st }}$ International Conference of Information Systems for Business Competitiveness (ICISBC), pp. 392-398.

Soegijoko, S, 2010, Perkembangan terkini telemedika dan e-health serta prospek aplikasinya di Indonesia, seminar nasional aplikasi teknologi informasi 2010 (snati 2010), issn $1907-5022$. 